Prepared in cooperation with the Louisiana Department of Transportation and Development

\title{
Water Resources of Vermilion Parish, Louisiana
}

\section{Introduction}

Information concerning the availability, use, and quality of water in Vermilion Parish, Louisiana (fig. 1), is critical for proper water-supply management. The purpose of this fact sheet is to present information that can be used by water managers, parish residents, and others for stewardship of this vital resource. Information on the availability, past and current use, use trends, and water quality from groundwater and surface-water sources in the parish is presented. Previously published reports (see References Cited section) and data stored in the U.S. Geological Survey's National Water Information System (http://waterdata.usgs.gov/nwis) are the primary sources of the information presented here.
In 2010, about 93.6 million gallons per day (Mgal/d) of water were withdrawn in Vermilion Parish, Louisiana, including about 61.9 Mgal/d from surface-water sources and $31.8 \mathrm{Mgal} / \mathrm{d}$ from groundwater sources ${ }^{1}$ (table 1). Withdrawals for rice irrigation $(62.5 \mathrm{Mgal} / \mathrm{d})$ accounted for about 67 percent of the total water withdrawn (table 2). Other categories of use included public supply, industrial, rural domestic, livestock, general irrigation, and aquaculture. Water-use data collected at 5-year intervals from 1960 to 2010 indicated that water withdrawals in the parish peaked in 1980 at about $548 \mathrm{Mgal} / \mathrm{d}$ and have since steadily declined (fig. 2).

\footnotetext{
'Water-withdrawal data are based on estimated or reported site-specific data and aggregated data, which are distributed to sources. For a full description of wateruse estimate methodology, see "Data Collection" in Sargent (2011). Tabulation of numbers in text and tables may result in different totals because of rounding; nonrounded numbers are used for calculation of totals.
}

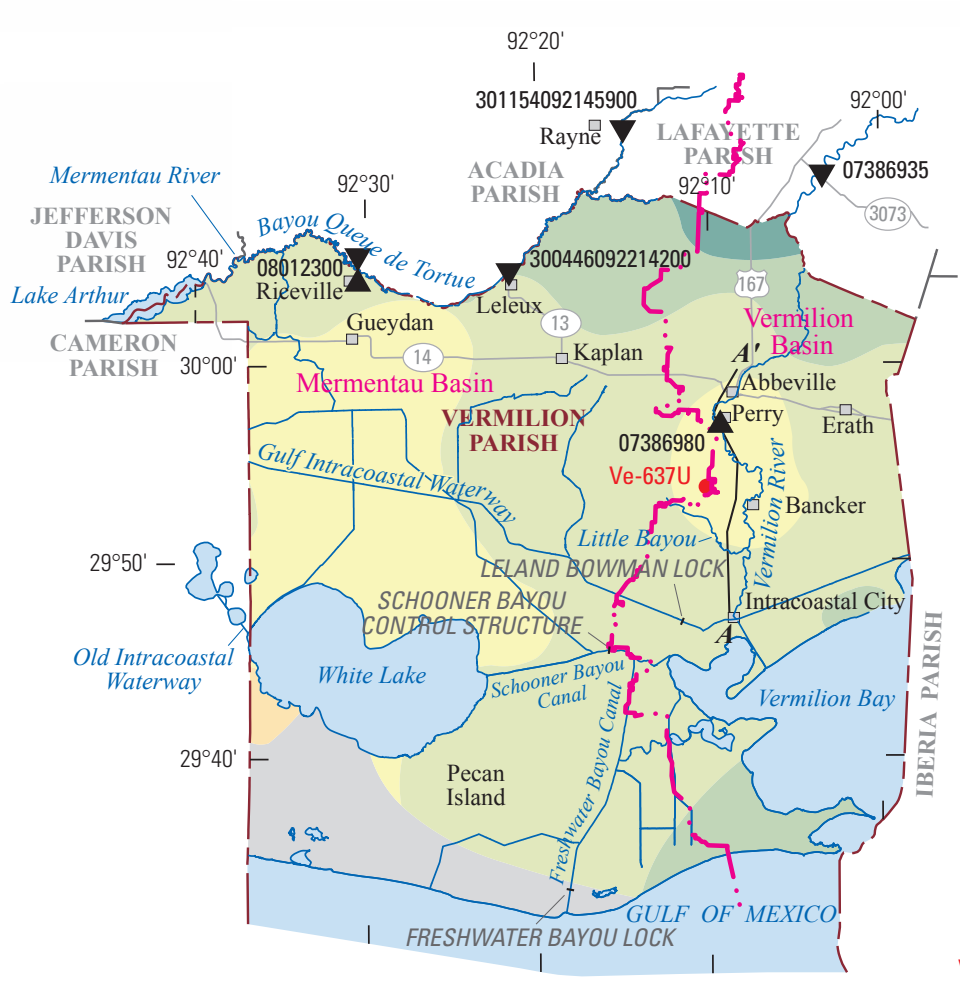

Base modified from U.S. Geological Survey digital data Albers Equal-Area Conic projection North American Datum of 1983

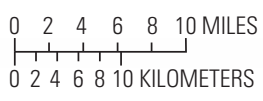

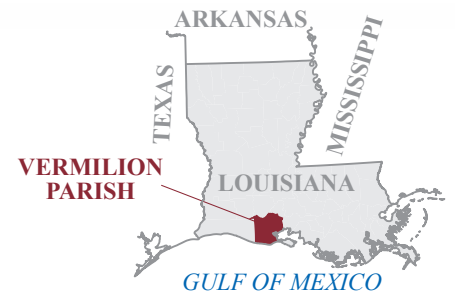

EXPLANATION

Approximate altitude of base of fresh groundwater, in feet below National Geodetic Vertical Datum of 1929 (NGVD 29) (modified from Smoot, 1988) - Deepest freshwater contained within Chicot aquifer system 0 to 299 300 to 499 500 to 699 700 to 899 900 to 1,199

\section{Approximate area where no major aquife contains freshwater \\ - - River basin boundary \\ $A-A^{\prime}$ Line of section (see fig. 3)}

Well and well number for which hydrograph is Ve-637U shown (see fig. 4) $07386980 \quad$ U.S. Geological Survey surfac
discharge site and number

U.S. Geological Survey surface-water quality site and number (see table 4)

Figure 1. Location of study area, Vermilion Parish, Louisiana. 
Table 1. Water withdrawals, in million gallons per day, by source in Vermilion Parish, Louisiana, 2010 (Sargent, 2011; B.P. Sargent, unpub. data, 2011).

\begin{tabular}{lcc}
\hline \multicolumn{1}{c}{$\begin{array}{c}\text { Aquifer system or } \\
\text { surface-water body }\end{array}$} & Groundwater & Surface water \\
\hline Chicot aquifer system & 31.75 & \\
Bayou Queue de Tortue & & 20.18 \\
Vermilion River & & 20.18 \\
Other streams & & 21.50 \\
\cline { 2 - 3 } Total & 31.75 & 61.86 \\
\hline
\end{tabular}

Table 2. Water withdrawals, in million gallons per day, by use category in Vermilion Parish, Louisiana, 2010 (modified from Sargent, 2011).

\begin{tabular}{lccc}
\hline \multicolumn{1}{c}{ Use category } & Groundwater & Surface water & Total \\
\hline Public supply & 6.39 & 0.00 & 6.39 \\
Industrial & 1.55 & 0.00 & 1.55 \\
Rural domestic & 2.29 & 0.00 & 2.29 \\
Livestock & 0.07 & 0.27 & 0.33 \\
Rice irrigation & 5.51 & 57.02 & 62.53 \\
General irrigation & 0.11 & 0.44 & 0.55 \\
Aquaculture & 15.83 & 4.14 & 19.97 \\
Total & 31.75 & 61.86 & 93.61 \\
\hline
\end{tabular}

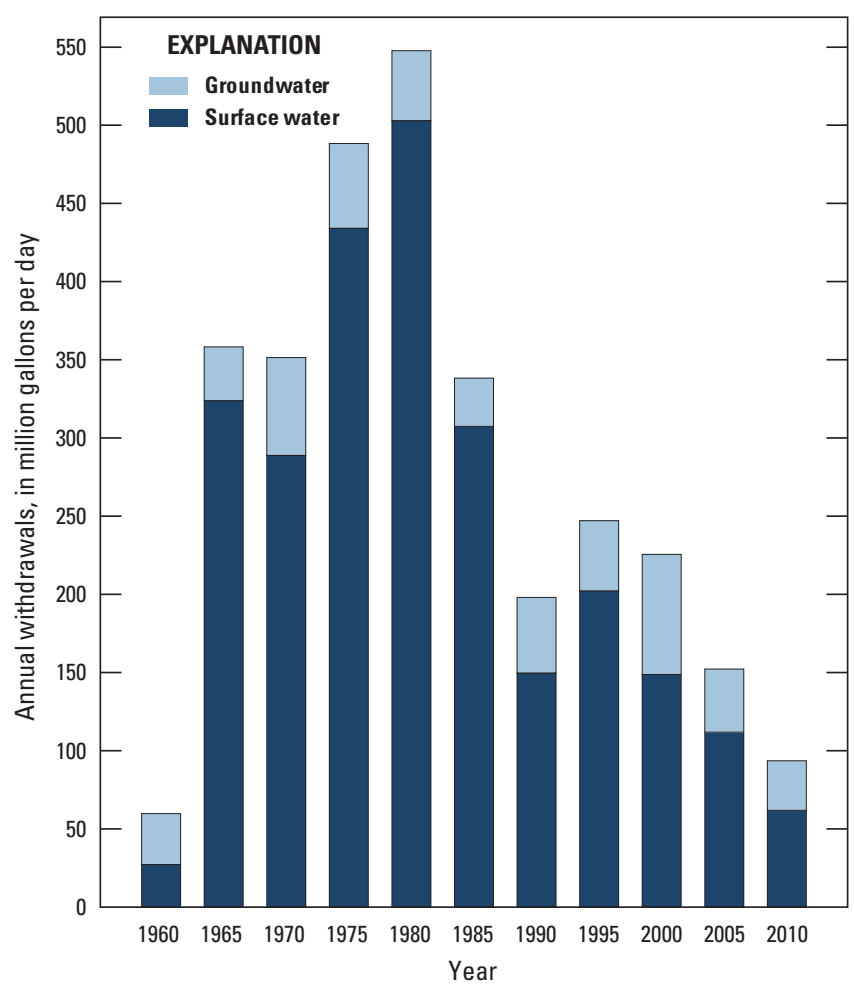

Figure 2. Water withdrawals in Vermilion Parish, Louisiana, 1960-2010 (Sargent, 2011).

\section{Groundwater Resources}

The Chicot aquifer system is the primary source of fresh groundwater (water with a chloride concentration of 250 milligrams per liter [mg/L] or less) in Vermilion Parish (fig. 3 ). Deeper aquifers in the parish contain saltwater (water with a chloride concentration greater than $250 \mathrm{mg} / \mathrm{L}$ ) (Smoot, 1986). The base of fresh groundwater is present in the Chicot aquifer system and generally ranges from less than 300 feet (ft) below the National Geodetic Vertical Datum of 1929 (NGVD 29) in southwestern Vermilion Parish to about 1,000 ft below NGVD 29 in northeastern Vermilion Parish (fig. 1; Smoot, 1988). No fresh groundwater is available in an area south of White Lake as indicated by the gray shading on figure 1.

In Vermilion Parish, the Chicot aquifer system comprises the shallow sand, upper sand, and lower sand. The aquifer system generally dips and thickens to the south. Recharge to the aquifer system is primarily by infiltration of precipitation where the aquifer system outcrops in parts of Allen, Beauregard, Evangeline, Rapides, and Vernon Parishes (Nyman, 1989). A computer model of the Chicot aquifer system indicated that additional recharge occurs throughout southwestern Louisiana where heavy pumping for irrigation induces infiltration through the surficial clay (Nyman and others, 1990). Discharge from the Chicot aquifer system is primarily by withdrawals from wells. In 2010, all reported groundwater withdrawals in Vermilion Parish came from the Chicot aquifer system. Various uses included public supply, industrial, rural domestic, livestock, rice irrigation, general irrigation, and aquaculture (table 2).

A surficial confining layer of clay and silt, which restricts the flow of groundwater, is generally present from land surface to depths ranging from less than $50 \mathrm{ft}$ to greater than $400 \mathrm{ft}$ below land surface throughout Vermilion Parish (Sargent, 2004). Within the surficial confining layer are scattered sand streaks, lenses, and layers collectively referred to as the "shallow sand." The shallow sand is less than $100 \mathrm{ft}$ thick in most areas of the parish; however, south of Abbeville, near Bancker (fig. 1), the shallow sand thickens to as much as $250 \mathrm{ft}$. In this area, the overlying confining layer thins to less than $20 \mathrm{ft}$ thick, and the underlying clay that separates the shallow sand from the upper sand is absent or less than $5 \mathrm{ft}$ thick in some areas (Harder and others, 1967). Saltwater is present in the shallow sand in this area (Lovelace, 1999). State well-registration records listed 2,429 active water wells screened in the shallow sand in Vermilion Parish in 2010, including 2,132 domestic, 171 irrigation, 37 industrial, and 89 public supply. Well depths ranged from 12 to $350 \mathrm{ft}$ below land surface, with a median depth of $100 \mathrm{ft}$. Reported yields from wells screened in the shallow sand in Vermilion Parish ranged from 2 to 3,600 gallons per minute (gal/min) (Louisiana Department of Natural Resources, 2010).

The upper sand, which underlies the surficial confining layer and shallow sand, contains freshwater throughout its areal extent in Vermilion Parish except in the southwestern corner where the upper sand contains only saltwater. Conflicting data indicated that a small area near Bancker may also have no freshwater in the upper sand. The upper sand generally contains freshwater throughout its thickness only in northern parts of the parish. Throughout most of the parish, freshwater in the upper sand is underlain with saltwater (Nyman, 1984). The top of the upper sand ranges from less than $200 \mathrm{ft}$ to more than $600 \mathrm{ft}$ below NGVD 29, and the base extends to about 1,200 ft or more below NGVD 29 within the parish (Nyman, 1984). State well-registration records listed 2,701 active water wells screened in the upper sand in Vermilion Parish in 2010, including 1,992 domestic, 527 irrigation, 114 public supply, and 68 industrial. Well depths ranged from about 60 to $716 \mathrm{ft}$ below land surface, with a median depth of $170 \mathrm{ft}$. Reported well yields have ranged from 2 to 5,975 gal/min (Louisiana Department of Natural Resources, 2010). 


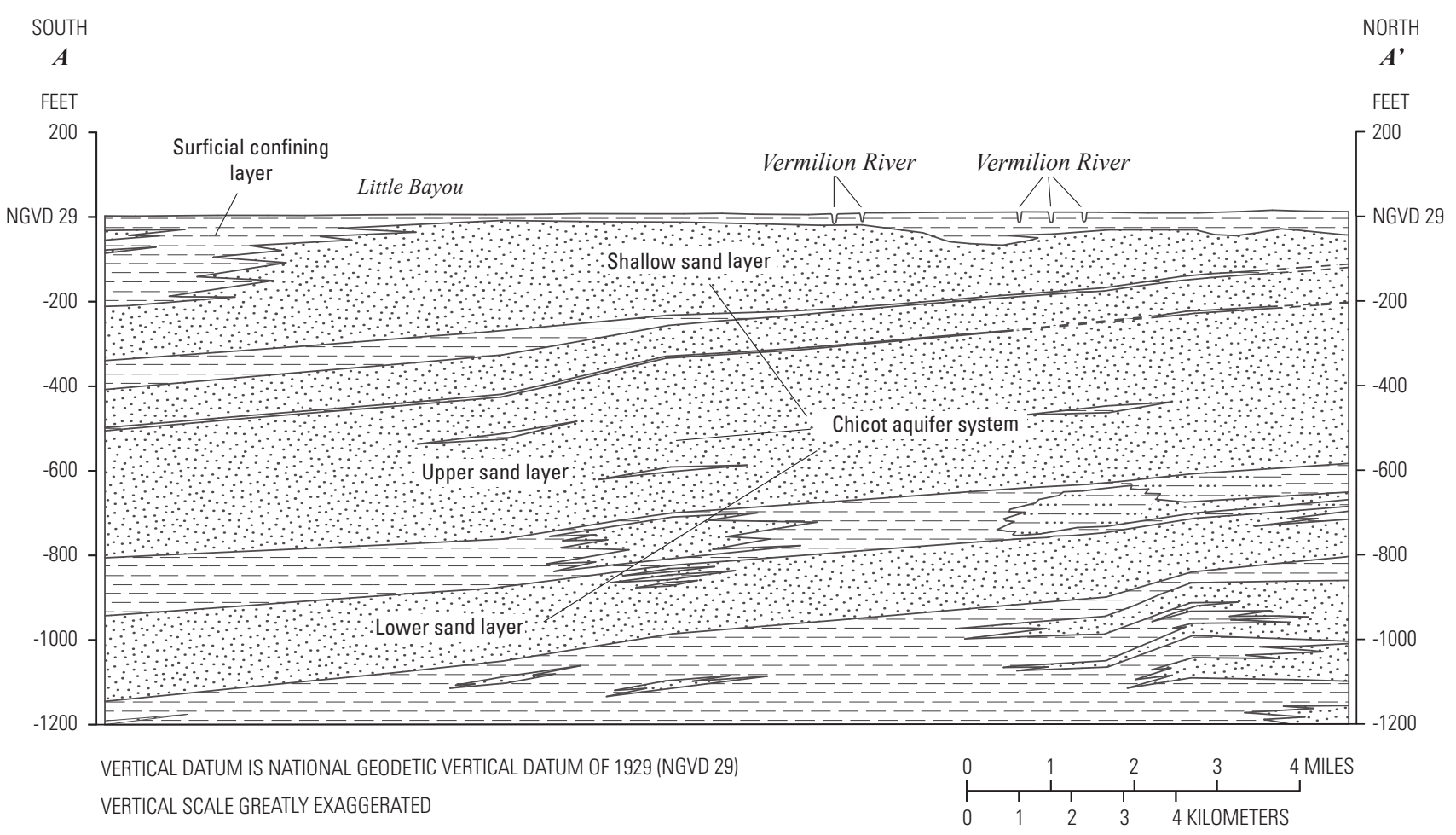

EXPLANATION

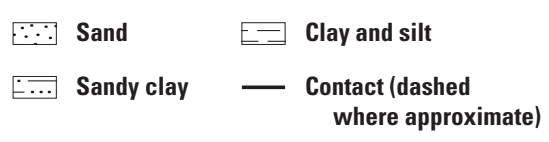

Figure 3. South-to-north hydrogeologic section showing sand layers in the Chicot aquifer system in Vermilion Parish, Louisiana (modified from Harder and others, 1967). Trace of section shown on figure 1.

A clay layer that ranges in thickness from less than $10 \mathrm{ft}$ to as much as $200 \mathrm{ft}$ underlies the upper sand and separates it from the lower sand. The lower sand contains freshwater only in the extreme northeastern corner of Vermilion Parish, along the borders with Lafayette and Acadia Parishes. In this area, freshwater is present to a depth of over $1,000 \mathrm{ft}$; south of this area, the lower sand contains only saltwater (Nyman, 1989). State well-registration records did not include any active wells screened in the lower sand in Vermilion Parish in 2010.

In January 2003, water levels in the Chicot aquifer system ranged from about the NGVD 29 near the coastline to about $35 \mathrm{ft}$ below NGVD 29 near the northwestern parish line (Lovelace and others, 2004). In 2003, the general direction of groundwater flow in the Chicot aquifer system in western Vermilion Parish was to the north, and in eastern Vermilion Parish, it was to the northwest (Lovelace and others, 2004). The direction of flow is a result of large groundwater withdrawals, primarily for rice irrigation, within Vermilion Parish and other parishes to the north and northwest. In Vermilion Parish, water levels in the Chicot aquifer system upper sand generally fluctuate from 1 to $3 \mathrm{ft}$ seasonally in response to seasonal water demands (fig. 4).

A statistical summary of selected water-quality characteristics for freshwater samples collected from 196 wells screened in the Chicot aquifer system in Vermilion Parish is listed in table 3. The median value for hardness, $200 \mathrm{mg} / \mathrm{L}$, is within the very hard range. ${ }^{2}$ Iron and manganese concentrations

\footnotetext{
${ }^{2}$ Hardness ranges, expressed as milligrams per liter of calcium carbonate, are as follows: 0-60, soft; 61-120, moderately hard; $121-180$, hard; greater than 180 , very hard (Hem, 1985).
}

generally exceed the U.S. Environmental Protection Agency's Secondary Maximum Contaminant Levels ${ }^{3}$ (SMCLs) for drinking water. The $\mathrm{pH}$ of the water is generally within the SMCL range of 6.5-8.5 standard units.

Saltwater encroachment into fresh groundwater supplies is a concern for Vermilion Parish. Prior to groundwater development, the direction of flow in the Chicot aquifer system was generally southward toward the coast. Pumping from the aquifer system within Vermilion Parish and in parishes to the north has changed the direction of groundwater flow. Presently, groundwater flows northward, providing a gradient for saltwater to move inland from the coast toward pumping centers (Lovelace, 1999).

\section{Surface-Water Resources}

In 2010, about $61.9 \mathrm{Mgal} / \mathrm{d}$ of surface water were withdrawn in Vermilion Parish (tables 1 and 2). Withdrawals for rice irrigation accounted for about 92 percent of all surface-water withdrawals. Other uses included livestock, general irrigation, and aquaculture. Surface-water sources included Bayou Queue de Tortue, Vermilion River, and other streams (table 1). Notable bodies of water in or bordering the parish include the Gulf of

${ }^{3}$ The SMCLs are nonenforceable Federal guidelines regarding cosmetic effects (such as tooth or skin discoloration) or aesthetic effects (such as taste, odor, or color) of drinking water. At high concentrations or values, health implications as well as aesthetic degradation might exist. SMCLs were established as guidelines for the States by the U.S. Environmental Protection Agency (1992). 


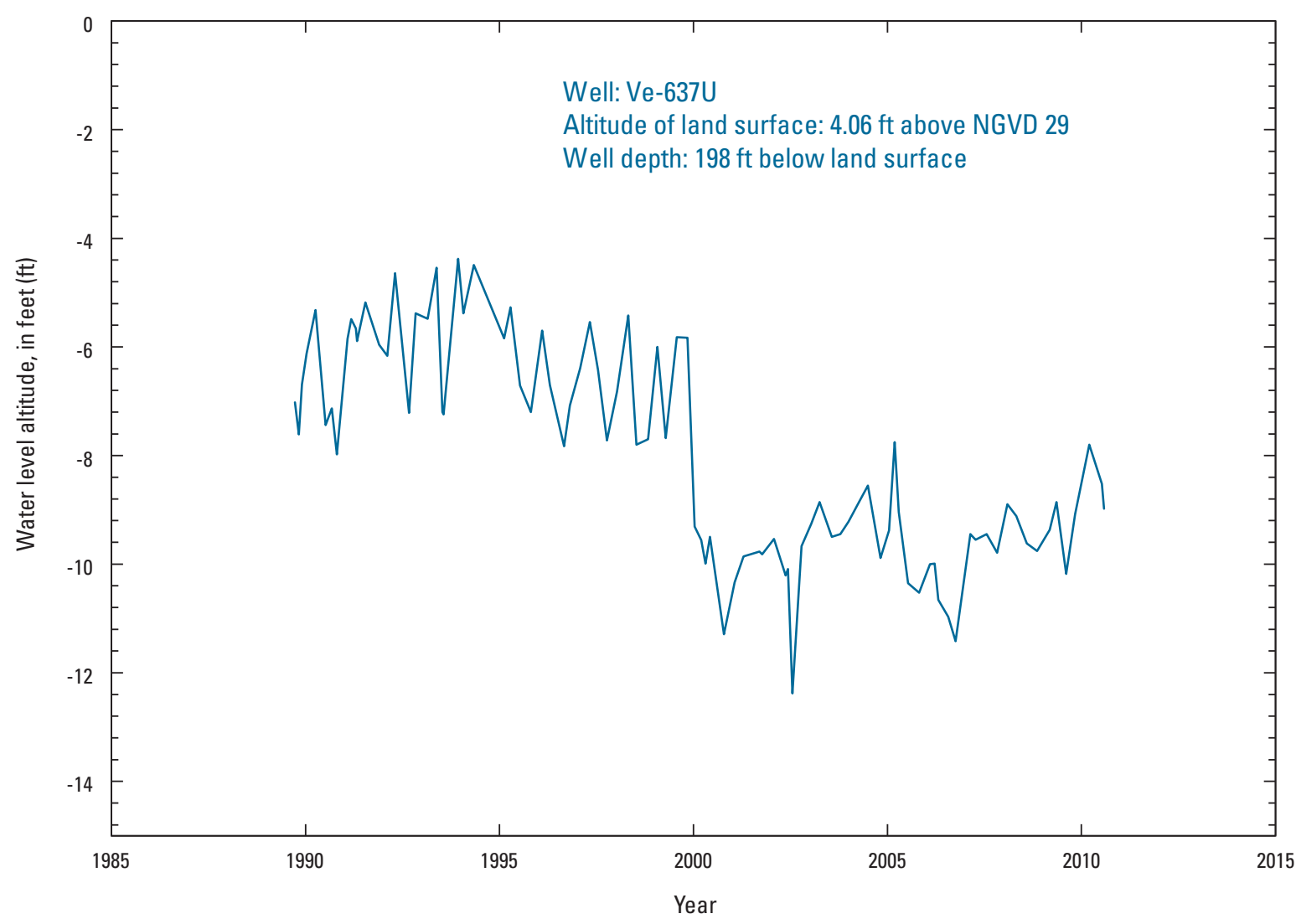

Figure 4. Water levels in well Ve-637U screened in the upper sand of the Chicot aquifer system in Vermilion Parish, Louisiana (see fig. 1 for well location; U.S. Geological Survey, 2010a). Altitude of land surface and water level are measured in feet ( $\mathrm{ft}$ ) relative to the National Geodetic Vertical Datum of 1929 (NGVD 29).

Table 3. Summary of selected water-quality characteristics for freshwater from the Chicot aquifer system in Vermilion Parish, Louisiana, 1944-2009 (U.S. Geological Survey, 2010b).

[Values are in milligrams per liter, except as noted. ${ }^{\circ} \mathrm{C}$, degrees Celsius; $\mathrm{PCU}$, platinum cobalt units; $\mu \mathrm{S} / \mathrm{cm}$, microsiemens per centimeter; $\mathrm{SU}$, standard units; $\mathrm{CaCO}_{3}$, calcium carbonate; $\mu \mathrm{g} / \mathrm{L}$, micrograms per liter; SMCL, Secondary Maximum Contaminant Level established by the U.S. Environmental Protection Agency (2012); NA, not applicable]

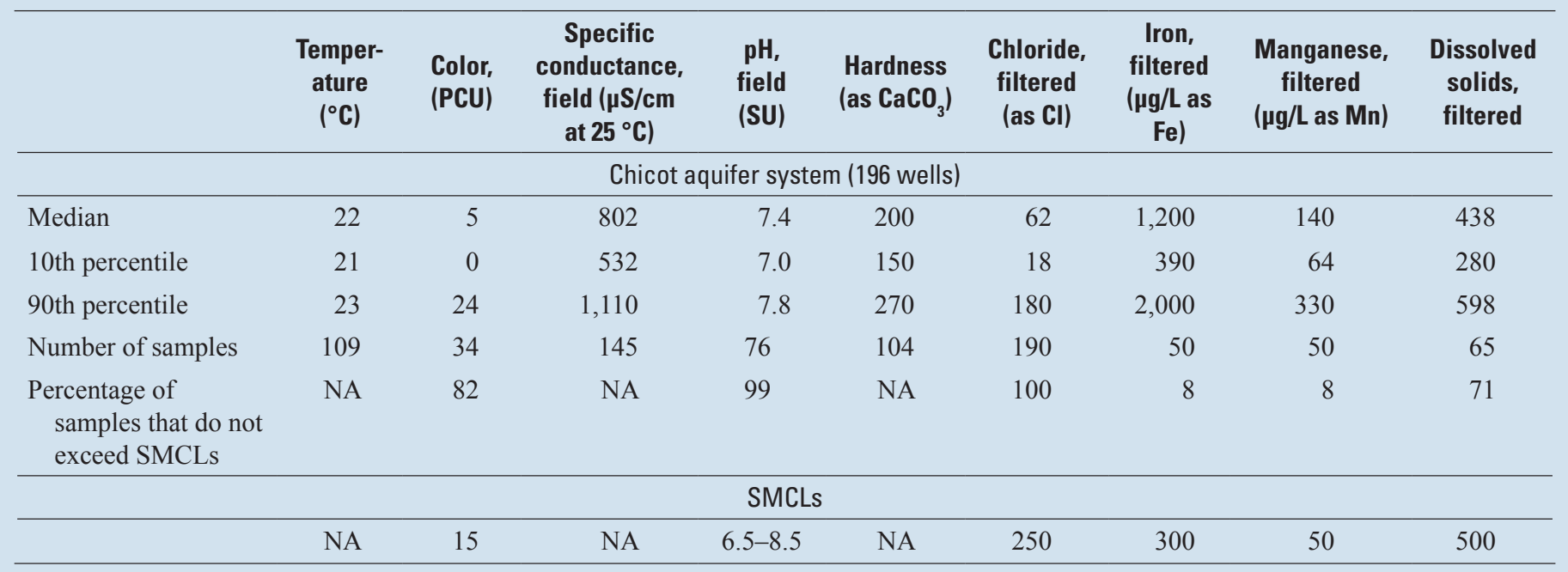

Mexico, the Gulf Intracoastal Waterway, the Mermentau River, Lake Arthur, White Lake, and Vermilion Bay (fig. 1). Vermilion Parish is divided into the Mermentau drainage basin in roughly the western two-thirds of the parish and the Vermilion drainage basin in the eastern one-third of the parish (fig. 1; U.S. Geological Survey, 2013a). As a coastal parish, the direction of water movement in these two basins is a concern in terms of consistent availability of fresh surface water. Saltwater intrusion from the
Gulf of Mexico into parish waterways could adversely affect wildlife, freshwater flora, and agriculture, particularly rice and crawfish production.

In 2010, about $20.2 \mathrm{Mgal} / \mathrm{d}$ of water were withdrawn in Vermilion Parish from the Vermilion River. During 1984-2012, the average daily discharge for the Vermilion River at Perry (site number 07386980 ; fig. 1) was 1,140 cubic feet per second $\left(\mathrm{ft}^{3} / \mathrm{s}\right)(737 \mathrm{Mgal} / \mathrm{d})$ (U.S. Geological Survey, 2013b). Reverse 
(upstream) flow in the river can occur during periods of low flow, sustained southerly winds, or high tides (Baker, 1988). Water samples from the Vermilion River collected a few miles upstream from Vermilion Parish in Lafayette Parish at State Highway 3073 (site number 07386935; fig. 1) during 1983-86 (table 4) indicated that, in general, the water is soft and does not exceed SMCLs for $\mathrm{pH}$ and concentrations of chloride, sulfate, and iron. The median value for dissolved oxygen concentration was $5.3 \mathrm{mg} / \mathrm{L}$. The minimum value for a diversified population of fresh, warmwater biota, including sport fish, is $5 \mathrm{mg} / \mathrm{L}$ of dissolved oxygen (Louisiana Department of Environmental Quality, 2008).

In 2010, about $20.2 \mathrm{Mgal} / \mathrm{d}$ of water were withdrawn from Bayou Queue de Tortue in Vermilion Parish. During 1985-90, the average daily discharge for Bayou Queue de Tortue at Riceville (site number 08012300; fig. 1) was about $364 \mathrm{ft}^{3} / \mathrm{s}$ (U.S. Geological Survey, 2013b). Reverse flow can occur at this site. A limited number of water samples collected from Bayou Queue de Tortue near Rayne (site number 301154092145900), Leleux (site number 300446092214200), and Riceville from 1989 to 2001 (table 4; fig. 1) indicated that, in general, the water is moderately hard to hard and does not exceed SMCLs for $\mathrm{pH}$ and concentrations of chloride, sulfate, and iron. Dissolved oxygen concentrations generally are below $5 \mathrm{mg} / \mathrm{L}$.
Lake Arthur is a shallow lake formed by a widening of the Mermentau River that feeds and drains the lake. The average altitude of the lake surface is estimated to be about $4 \mathrm{ft}$ above NGVD 29. At this altitude, the lake has a surface area of about 6 square miles $\left(\mathrm{mi}^{2}\right)$ and an average depth of about $7 \mathrm{ft}$ (Shampine, 1971). White Lake is a natural water body with a surface area of $81 \mathrm{mi}^{2}$ and an average depth of $4.5 \mathrm{ft}$. The main source of inflow to White Lake is the Old Intracoastal Waterway, which indirectly receives flow from the Mermentau River in neighboring Cameron Parish. Presently, White Lake contains mostly freshwater. Prior to the construction of control structures in the Mermentau Basin during 1950-86 (U.S. Army Corps of Engineers, n.d.), White Lake contained brackish water (water which contains between 1,000 and $10,000 \mathrm{mg} / \mathrm{L}$ of dissolved solids) because of saline water (water which contains 1,000$35,000 \mathrm{mg} / \mathrm{L}$ of dissolved solids) intrusion from the Gulf of Mexico (Shampine, 1971).

The Gulf Intracoastal Waterway, which traverses central Vermilion Parish in a general east-west direction, is the largest continuous ship channel in coastal Louisiana (Swarzenski, 2003). The U.S. Army Corps of Engineers maintains various control structures, including the Leland Bowman Lock, the Schooner Bayou Control Structure, and the Freshwater Bayou

Table 4. Summary of selected water-quality characteristics for the Vermilion River and Bayou Queue de Tortue, Louisiana (U.S. Geological Survey, 2010b).

[Values are in milligrams per liter, except as noted. $\mu \mathrm{S} / \mathrm{cm}$, microsiemens per centimeter; ${ }^{\circ} \mathrm{C}$, degrees Celsius; $\mathrm{SU}$, standard units; $\mathrm{CaCO}_{3}$, calcium carbonate; $\mu \mathrm{g} / \mathrm{L}$, micrograms per liter; SMCL, Secondary Maximum Contaminant Level established by the U.S. Environmental Protection Agency (2012); NA, not applicable; E, estimated (result was extrapolated outside the calibration curve, see Childress and others, 1999)]

\begin{tabular}{|c|c|c|c|c|c|c|c|c|c|c|}
\hline & $\begin{array}{c}\text { Specific } \\
\text { conductance, } \\
\text { field }(\mu \mathrm{S} / \mathrm{cm} \\
\left.\text { at } 25^{\circ} \mathrm{C}\right)\end{array}$ & $\begin{array}{l}\text { Oxygen, } \\
\text { dis- } \\
\text { solved }\end{array}$ & $\begin{array}{l}\text { pH, } \\
\text { field } \\
\text { (SU) }\end{array}$ & $\begin{array}{l}\text { Hardness } \\
\text { (as } \mathrm{CaCO}_{3} \text { ) }\end{array}$ & $\begin{array}{l}\text { Calcium, } \\
\text { filtered } \\
\text { (as Ca) }\end{array}$ & $\begin{array}{c}\text { Mag- } \\
\text { nesium, } \\
\text { filtered } \\
\text { (as } \mathrm{Mg} \text { ) }\end{array}$ & $\begin{array}{l}\text { Sodium, } \\
\text { filtered } \\
\text { (as Na) }\end{array}$ & $\begin{array}{c}\text { Chloride, } \\
\text { filtered } \\
\text { (as CI) }\end{array}$ & $\begin{array}{l}\text { Sulfate, } \\
\text { filtered } \\
\text { (as S04) }\end{array}$ & $\begin{array}{c}\text { Iron, } \\
\text { filtered } \\
\text { ( } \mu \mathrm{g} / \mathrm{L} \\
\text { as Fe) }\end{array}$ \\
\hline \multicolumn{11}{|c|}{ Vermilion River at State Hwy 3073 at Lafayette, $1983-86^{1}$} \\
\hline Median & 143 & 5.3 & 7.1 & 43 & 11 & 4.0 & 10 & 12 & 10 & 190 \\
\hline 10th percentile & 87 & 3.7 & 6.2 & 27 & 7.1 & 2.2 & 5.5 & 6 & 5.2 & 140 \\
\hline $\begin{array}{c}\text { Number of } \\
\text { samples }\end{array}$ & 13 & 13 & 13 & 13 & 13 & 13 & 13 & 13 & 13 & 3 \\
\hline $\begin{array}{l}\text { Percentage of } \\
\text { samples that } \\
\text { do not exceed } \\
\text { SMCLs }\end{array}$ & NA & NA & 100 & NA & NA & NA & NA & 100 & 100 & 100 \\
\hline 10th percentile & 235 & 0.9 & 7.3 & 56 & 14 & 5.2 & 19 & 14 & 2.3 & E9 \\
\hline 90th percentile & 636 & 4.9 & 8.2 & 140 & 32 & 15 & 90 & 60 & 8.2 & 80 \\
\hline $\begin{array}{c}\text { Number of } \\
\text { samples }\end{array}$ & 18 & 17 & 18 & 18 & 18 & 18 & 16 & 16 & 17 & 17 \\
\hline $\begin{array}{l}\text { Percentage of } \\
\text { samples that } \\
\text { do not exceed } \\
\text { SMCLs }\end{array}$ & NA & NA & 100 & NA & NA & NA & NA & 100 & 100 & 100 \\
\hline \multicolumn{11}{|l|}{ SMCLs } \\
\hline & NA & NA & $6.5-8.5$ & NA & NA & NA & NA & 250 & 250 & 300 \\
\hline
\end{tabular}

${ }^{1}$ Site number 07386935.

${ }^{2}$ Site numbers 08012300, 301154092145900, 300446092214200. 
Lock (fig. 1), to direct floodwaters, maintain freshwater for irrigation, and restrict movement of saltwater from the Gulf of Mexico into the Gulf Intracoastal Waterway and other coastal waterways in the parish (U.S. Army Corps of Engineers, n.d.).

\section{References Cited}

Baker, N.T., 1988, Hydrologic features and processes of the Vermilion River, Louisiana: U.S. Geological Survey Water-Resources Investigations Report 88-4019, 49 p., accessed November 8, 2012, at http://pubs.er.usgs.gov/ publication/wri884019.

Childress, C.J. Oblinger, Foreman, W.T., Connor, B.F., and Maloney, T.J., 1999, New reporting procedures based on long-term method detection levels and some considerations for interpretations of water-quality data provided by the U.S. Geological Survey National Water Quality Laboratory: U.S. Geological Survey Open-File Report 99-193, 19 p.

Harder, A.H., Kilburn, Chabot, Whitman, H.M., and Rogers, S.M., 1967, Effects of ground-water withdrawals on water levels and saltwater encroachment in southwestern Louisiana: Department of Conservation, Louisiana Geological Survey, and Louisiana Department of Public Works Water Resources Bulletin no. $10,56 \mathrm{p}$

Hem, J.D., 1985, Study and interpretation of the chemical characteristics of natural water (3d ed.): U.S. Geological Survey Water-Supply Paper 2254, 264 p., accessed February 20, 2013, at http://pubs.er.usgs.gov/publication/wsp2254.

Louisiana Department of Environmental Quality, 2008, Environmental Regulatory Code, Title 33, Part IX, Subpart 1: Baton Rouge, Louisiana Department of Environmental Quality, accessed June 9, 2009, at http:www.deq.louisiana.gov/ portal/tabid/1674/Default.aspx.

Louisiana Department of Natural Resources, 2010, Strategic Online Natural Resources Information System (SONRIS): Louisiana Department of Natural Resources database, accessed August 18, 2010, at http://sonris.com/.

Lovelace, J.K., 1999, Distribution of saltwater in the Chicot aquifer system of southwestern Louisiana, 1995-96: Louisiana Department of Transportation and Development Water Resources Technical Report no. 66, 61 p.

Lovelace, J.K., Fontenot, J.W., and Frederick, C.P., 2004, Withdrawals, water levels, and specific conductance in the Chicot aquifer system in southwestern Louisiana, 2000-03: U.S. Geological Survey Scientific Investigations Report 2004-5212, 56 p., accessed July 25, 2012, at http://pubs.er.usgs.gov/publication/ $\operatorname{sir} 20045212$.

Nyman, D.J., 1984, The occurrence of high concentrations of chloride in the Chicot aquifer system of southwestern Louisiana: Louisiana Department of Transportation and Development, Office of Public Works Water Resources Technical Report no. 33, 75 p.

Nyman, D.J., 1989, Quality of water in freshwater aquifers in southwestern Louisiana: Louisiana Department of Transportation and Development Water Resources Technical Report no. 42, 22 p., 28 pls

Nyman, D.J., Halford, K.J., and Martin, Angel, Jr., 1990, Geohydrology and simulation of flow in the Chicot aquifer system of southwestern Louisiana: Louisiana Department of Transportation and Development Water Resources Technical Report no. 50, $58 \mathrm{p}$

Sargent, B.P., 2004, Thickness of the Chicot aquifer system surficial confining unit and location of shallow sands, southwestern Louisiana: Louisiana Department of Transportation and Development Water Resources Technical Report no. 73, 29 p.

Sargent, B.P., 2011, Water use in Louisiana, 2010: Louisiana Department of Transportation and Development Water Resources Special Report no. 17, 135 p.

Shampine, W.J., 1971, Chemical, biological, and physical data for the major lakes and reservoirs in Louisiana: Louisiana Department of Public Works Basic Records Report no. 5, 98 p.
Smoot, C.W., 1986, Louisiana hydrologic atlas map no. 2-Areal extent of freshwater in major aquifers of Louisiana: U.S. Geological Survey WaterResources Investigations Report 86-4150, 1 sheet, accessed January 18, 2012, at http://pubs.er.usgs.gov/publication/wri864150.

Smoot, C.W., 1988, Louisiana hydrologic atlas map no. 3-Altitude of the base of freshwater in Louisiana: U.S. Geological Survey Water-Resources Investigations Report 86-4314, 1 sheet, accessed November 2, 2011, at http:// pubs.er.usgs.gov/publication/wri864314.

Swarzenski, C.M., 2003, Surface-water hydrology of the Gulf Intracoastal Waterway in south-central Louisiana, 1996-99: U.S. Geological Survey Professional Paper 1672, $51 \mathrm{p}$

U.S. Army Corps of Engineers, [n.d.], The Mermentau Basin Project: U.S. Army Corps of Engineers, New Orleans District, accessed August 23, 2010, at http:// www.mvn.usace.army.mil/Portals/56/docs/PAO/Brochures/mermentau.pdf.

U.S. Environmental Protection Agency, 1992, Secondary drinking water regulations - Guidance for nuisance chemicals: U.S. Environmental Protection Agency publication EPA 810/K-92-001, 4 p., accessed September 28, 2011, at http://water.epa.gov/drink/contaminants/secondarystandards.cfm.

U.S. Environmental Protection Agency, 2012, 2012 Edition of the drinking water standards and health advisories: U.S. Environmental Protection Agency publication EPA 822-S-12-001, Office of Water, 12 p., accessed August 7, 2012, at http://water.epa.gov/action/advisories/drinking/upload/ dwstandards2012.pdf.

U.S. Geological Survey, 2010a, Groundwater levels for Louisiana [data for USGS 295345092100702 Ve-637U]: National Water Information System Web Interface, accessed August 17, 2010, at http://nwis.waterdata.usgs.gov/la/nwis/ gwlevel/?site_no $=295345092100702$.

U.S. Geological Survey, 2010b, Water quality samples for Louisiana: National Water Information System Web Interface, accessed May 22, 2010, at http:// nwis.waterdata.usgs.gov/la/nwis/qwdata/.

U.S. Geological Survey, 2013a, Science in your watershed - Locate your watershed: Lower Mississippi, accessed December 12, 2013, at http://water. usgs.gov/wsc/reg/08.html.

U.S. Geological Survey, 2013b, Surface-water daily statistics for the Nation: National Water Information System Web Interface, accessed December 9, 2013, at http://waterdata.usgs.gov/nwis/dvstat/?referred_module=sw.

This fact sheet was published by the U.S. Geological Survey, in cooperation with the Louisiana Department of Transportation and Development (DOTD). Thanks are given to Zahir "Bo" Bolourchi, Director, Water Resources Programs, DOTD, who contributed to the content of the fact sheet.

\section{By Lawrence B. Prakken and Vincent E. White}

\section{For additional information, contact:}

Director, USGS Lower Mississippi-Gulf Water Science Center 3535 S. Sherwood Forest Blvd., Suite 120

Baton Rouge, LA 70816

E-mail: gs-w-lmg_center_director@usgs.gov

Fax: (225) 298-5490

Telephone: (225) 298-5481

Home Page: http://la.water.usgs.gov 